\title{
VIELÄ MARXILAISESTA USKONTOKRITIIKISTÄ
}

\section{Paras Ilkka!}

Edellisessä Tiede \& edistyksen numerossa $(4 / 80)$ oli sinun arvostelu kirjastani Marxilainen uskontokritiikki. Se oli yksi niistä harvoista syvemmälle yrittävistä kommenteista, joita aikaansaannokseni oli lehdissä herättänyt (täsmällisemmin sanoen, toinen edellinen oli Jukka Heiskasen arvio Hälläpyörässä $1 / 80$ ). Siksi minun tekee mieleni vastata siihen edes lyhyesti.

Kiinnität huomiota siihen, että käytän Spinozan argumentteja ateistisen teoriani lähtökohtana ja rakennuskivinä. Mielestäni tämä on legitiimiä, sillä katson todellakin, että Spinoza on esittänyt näkemyksiä, iotka ovat päteviä myös marxilaisen filosofian kontekstissa. Tämä taas johtuu ennen kaikkea Spinozan materialistisesta monismista, joka tähtää kartesiolaisen dualismin voittamiseen. Sikäli kun pidämme Descartesin oppia eräänä porvarillisen "rationaliteetin tyypin" klassisena kirjaanpanona, on Spinozan siihen kohdistamalla kritiikillä relevanssia marxilaisuudenkin kannalta. Huomautan sivumennen, että myös Lenin käytti Materialismissa ja empiriokritisismissä hyväkseen esimarxilaisen materialismin argumentteja arvioidessaan tuolloin syntyneitä uusimpia idealistisia virtauksia; hän ei sitäpaitsi tyytynyt paljastamaan niiden luokkafunktioita, vaan piti filosofiaa omana argumentaatiolajinaan.

Sinä esität kuitenkin epäilyjä Spinozan materialismin "aitoudesta". Siteeraat pätkän, jossa Spinoza puhuu jumalasta, tosin samaistaen tämän luontoon eli substanssiin. "Mutta siitä huolimatta", jatkat sinä, "on olemassa jumala, joka empiirisesti samaistuu tämän maailman kanssa, mutta joka samalla on erotettavissa siitä käsitteellisesti"'. Mielestäsi on problemaattista nähdä Spinozan puhe "jumalasta" vain sellaiseksi, jossa termi "jumala" voidaan korvata materialistisesti tul- kitulla termillä "'luonto".

Ilkka hyvä, minusta tuntuu, että olet itse jo tavallaan omassa tekstissäni huomaamattasi vastannut esittämääsi kysymykseen. Sanoit nimittäin jumalan samaistuvan tämän maailman kanssa, mutta olevan samalla erotettavissa siitä käsitteellisesti. Niinpä niin, tässä onkin koko asian ydin: voimme tietysti muodostaa jumalan käsitteen ja ajatuksellisesti erottaa sen todellisesta maailmasta, mutta se ei toki tee jumalaa sen reaalisemmaksi.

Spinozan näkemys on se, että tarkastellessaan luontoa ihmiset muodostavat itselleen epäadekvaattisen idean luontoa ylläpitävästä jumalasta, vaikka luonto todellisuudessa on itse itsensä ylläpitäjä. Tätä ajatusta pyrin dokumentoimaan kirjassani.

Myös puheeni uskonnon (ja yleisemmin: idealistisen ajattelun) "negatiivisesta" luonteesta perustuu Spinozan totuusteorian hyväksikäytölle. Spinozahan toteaa tunnetusti, että ''ideoissa ei ole mitään positiivista, jonka mukaan niitä voisi nimittää epätosiksi" (Eth. II prop. 33), ts. väärä idea on pelkkää tiedostuksen poissaoloa. Se on tietämättömyyttä niistä todellisista seikoista, jotka determinoivat kaikkia olioita.

En suinkaan kirjassani väitä, kuten kirjoitat, että ' ulkoisten determinaatioiden voittaminen ei ole mahdollista" ja siksi "voittamiseen tähtäävät tajunnan muodot ovat illusorisia ja siis negatiivisia". Noin armoton deterministi en sentään ole! Olen päinvastoin korostanut, että mahdollisuus determinaatioiden "voittamiseen" syntyy, kun kyetään tiedostamaan adekvaattisesti niiden vaikuttavat syyt. Mutta nimenomaan tässä ei uskonto voi olla avuksi. Sehän asettaa todellisten syiden sijaan illusoriset.

Kirjassani esittämäni väite, jonka mukaan uskontoon, sikäli kuin se on uskontoa, ei sisälly mitään positiivista (nimittäin myönteistä ajatussisältöä), on vetänyt puoleensa monien muidenkin kuin sinun huomion. Tunnustan, että olen valinnut tällaisen muotoilun osittain pour épater le bourgeois, 'porvaria hätkäyttääkseni"'. Sellainen on kivaa, ja tuskin tulen tästä tavastani jatkossakaan luopumaan.

Mutta oli minulla vakavampikin aikomus silmieni edessä. Pyrin formuloimaan filosofiseksi väittämäksi sen historian oikeaksi osoittaman kokemuksen, että mikä tahansa "tosi uskonto" on mahdoton ja edistyksellisten ihmisten kannalta täysin hyödytön kangastus. Radikaaleja aatteita on puettu uskonnon hahmoon - kyllä, mutta "ansio" tästä ei kuulu itse uskonnolle, vaan olosuhteille, jotka ovat nuo radikaalit aatteet synnyttäneet. Väitän siis, että aina kun ollaan kyetty osoittamaan jokin uskonnollisen maailmankatsomuksen piiriin kuulunut ajatus myönteiseksi (kognitiivisesti relevanssiksi), humanistiseksi, ihmisen "olemusta vastaavaksi" todellisen elämän tehtävien tasolla jne., osoittautuu samalla, ettei se olekaan uskontoa. Olen halunnut näinkin jyrkästi painottaa "todellisen" uskonnon, "emansipatorisen" uskonnon mahdottomuutta, koska viime aikoina on taas alkanut näkyä kaikenlaista jumalanrakentamista työväenliikkeenkin liepeillä; viittaan vain vaikkapa eräisiin Uudistuva ihmiskunta -lehden numeroihin. Paras mahdollinen uskonto osoittautuu itse asiassa kaiken uskonnon kieltämiseksi - ateismiksi.

Sanot, ettei erotteluni "positiivisten ja negatiivisten tajunnanmuotojen" välillä ole johdonmukaisesti vietävissä läpi. Jos kiistämme "negatiivisen" reaalisuuden, tällainen erottelu muuttuu tietenkin hyvin problemaattiseksi vaatimukseksi, koska negatiivinen ei silloin enää ole mitään itsenäiștä, joka voitaisiin poimia muusta todellisuudesta (tai sen heijastuksesta) syrjään. Spinozankaan aikalaiset eivät ymmärtäneet häntä, kun hän menetel- 
mälleen uskollisena kiisti pahan siis "negatiivisen" - reaalisuuden. Kirjeessään Blyenberghille (13. III. 1665) hän yritti selittää: 'Uskon riittävästi osoittaneeni, että se, mikä muodostaa pahan, erehdyksen, rikoksen jne. olemisen (forma), ei koostu mistään, mikä ilmaisee olemusta, ja siksi emme voi sanoa, että jumala olisi sen syynä. Esimerkiksi Neron tekemä äidinmurha, sikäli kuin siihen sisältyi jotain positiivista, ei ollut rikos; sillä ulkoisesti samoin ja samalla äidin tappoaikeella toimi Orestes, eikä häntä kuitenkaan syytetä, ei ainakaan yhtä paljon kuin Neroa."

Syvennät arvosteluasi vielä yhdellä argumentilla. Otetaan joukko ihmisiä, jotka viettävät uskonnollista elämäntapaa. Koska näin on, niin uskonto ohjaa heidän käyttäytymistään, so. se on "determinoimassa sitä, mitä yksilöt tekevät" eikä siis voi olla pelkkää negatiivisuutta, koska se kerran kykenee aikaansaamaan determinaatiota. Argumenttisi ei minusta ole pätevä. Ensinnäkin, ajattelu ei determinoi olemista. (Puhun tästä enemmän kirjani sivuilla $23-24$ ja 38). Toiseksi, tuohon, mitä erittelemättä nimität "uskonnolliseksi elämäntavaksi", kuuluu todellisuudessa paljon "olemusta ilmaisevaa" (nimittäin ihmisolemuksen myöntämiseen pyrkivää) ainesta - aivan kuten Neron äidinmurhaankin. Ja tuo myönteinen aines on sellaista, mikä voitaisiin hyvin sisällyttää ateistiseenkin humanistiseen kulttuuriin. - Viinin ja ehtoollisviinin välillä ei ole muuta eroa kuin että jälkimmäiseen liittyy tietty illuusio; kummastakin pääsee humalaan, eikä mielestäni ole oikein sanoa, että ehtoollisviinistä saatu humala olisi "uskonnon determinoimaa".

Sanot, ettei ihmisten uskonnollista käyttäytymistä arvioitaessa ole kysymys siitä, mikä totuusarvo asetetaan uskonnollisille asenteille. No hyvä! On totta, että sokeakin kana löytää välistä jyvän. Kuitenkin olisi kanan itsensä kannalta epäilemättä parempi, että sillä olisi terveet silmät. Samoin en minäkään ole pyrkinyt arvioimaan uskonnon merkitystä vain tietoteoreettiselta kannalta, vaan ennen kaikkea ihmisen emansipaation kannalta. Huolimatta siitä, että uskonnollisesti käyttäytyvä ihminen saattaa kyetä tavoittamaan merkittäviä osatotuuksia, on hän silti, sikäli kuin hän uskoo yliluonnollisiin asioihin, sellaisten illuusioiden vallassa, jotka eivät edesauta hänen emansipaatiotaan.

Yleensäkin: en ole väittänyt, että kaikki se, mikä nykyisin kulkee uskonnon nimellä, olisi "negatiivista tajunnanmuotoa'. Olen sanonut: uskontoon, sikäli kun se on uskontoa, ei sisälly mitään myönteistä. Tuota pientä sanaa "sikäli" et ole havainnut, vaikka juuri se olisi avain päättelyjeni ymmärtämiseen. Itse asiassa tuo "sikäli" muuttaa lauseeni sellaiseksi, mitä positivistit ovat tavanneet nimittää 'tautologioiksi"'. Sitä ei voi kumota. Toisin kuin positivistit, en pidä tätä asiaintilaa pelkästään puutteena. Nähdäkseni lauseeni "tautologinen" muoto ei tosin tuo mitään uutta tiedon sisältöön nähden, mutta silti täydellistää tiedon muotoa: kuten sanoin, olen halunnut ilmaista näin sen historiasta saadun kokemuksen, ettei "myönteinen" uskonto ole mahdollista. Siis: sikäli kuin se on uskontoa . . .

Ja lopuksi. Löydät Leninin ja minun väliltä eroja suhtautumisesta uskovaisiin puolueen jäseninä, vaikka myönnätkin minun lainaavan oikeita kohtia Leniniltä. Sitaatit sitaatteina, mutta olisin toivonut sinulta suurempaa tarkkuutta, kun annat ymmärtää minun kirjoittavan, että yhteistyö kristittyjen kanssa on kommunisteille väline, joka on proletariaatin luokkaeduille alisteinen. Annat viitteen kirjani sivulle 181 . Siinä en kuitenkaan puhu uskovaisista välineinä, vaan päinvastoin totean, että ateistinen valistustyö on työväen luokkaeduille alisteista.
Siteeraat myös Leniniltä vain sen kohdan, missä hän sallii uskovaisten tulon puolueen jäseniksi. Kuitenkaan Lenin ei ole koskaan sanonut, että tämä pätisi kaikkiin tapauksiin. Sitaatin jatko näet kuuluu: "'Mutta jos esimerkiksi pappi liittyisi sosialidemokraattiseen puolueeseen ja alkaisi . . pääasiallisena ja melkein ainoana työnään saarnata aktiivisesti uskonnollisia katsomuksia, niin puolueen olisi ehdottomasti erotettava hänet riveistään."

Ilkka hyvä, se että puhuu niistä kriteereistä, joita jollakin ihmisellä pitää olla päästäkseen tietyn puolueen jäseneksi, ei merkitse hänen välineellistämistään ihmisenä. Vai koetko persoonallisuutesi manipulaatioksi sen, että sinulta vaaditaan ajokorttia ennen kuin pääset rattiin?

Totus tuus Vesa Oittinen 